\title{
The Urgency Development of Attractiveness in Bukit Khayangan Tourism Object Sungai Penuh City
}

Doli Witro (Orcid ID: 0000-0003-3332-2252)a, 1, Luqyana Azmiya Putri a, 2, Rabiyatul Adawiyah a, 3, Kesi Afrilia a, 4 , Nurul Alamin b, 5

1doliwitro01@gmail.com, ${ }^{2}$ luqyana.zmy@gmail.com, ${ }^{3}$ rabiyatulq334@gmail.com, ${ }^{4}$ kesiafrilia@gmail.com, 5nurulalamin02@gmail.com

${ }^{a}$ Institut Agama Islam Negeri (IAIN) Kerinci, Jl. Pelita IV, Sungai Penuh, Sumur Gedang, Kerinci, Jambi, 37112 Indonesia

b Madrasah Aliyah Negeri (MAN) 1 Kerinci, Jl. Perintis Depati Parbo Simpang IV, Sebukar, Sitinjau Laut, Kerinci, Jambi 37171 Indonesia

\begin{abstract}
In the era of globalization, the tourism sector is one of the largest and most influential industries in economic development in general. In the 21st century, the tourism sector will be the primary driver in the world economy. In tourism, there are elements contained in it, ranging from tourists, travel, tourist destinations, industry, and so forth. Tourism for foreign exchange sources, including Indonesia, which is one of the countries that have various types of tourism, namely natural tourism, social tourism, and cultural tourism spread from Sabang to Merauke. One of the regions in Indonesia where multiple types of natural wealth have the potential to be developed is Sungai Penuh City, located in the western area in the form of a plateau. The most popular highland tourist destination in Sungai Penuh City is Bukit Khayangan. Departing from the above, the author intends to develop these problems and raise them into an article that illustrates and discusses supporting factors and inhibiting factors in the development of the Bukit Khayangan attraction, Sungai Penuh City. Then the development of attractions in Bukit Khayangan, Sungai Penuh City city, as well as the contribution of Bukit Kayangan Kota Sungai Penuh attraction.
\end{abstract}

\section{Keyword: Object Development, Tourist Attraction, Bukit Khayangan}

\section{INTRODUCTION}

In the era of globalization, the tourism sector is one of the largest and most influential industries in economic development in general. In the 21st century, the tourism sector will become a significant driver in the world economy (Soebagyo, 2012: 153). Each country is currently competing to develop the existing tourism potential to compete with other countries.

In tourism, there are elements contained therein ranging from tourists, travel, tourist destinations, industry, etc. which are all forms of tourism activities. Tourism is the mainstay for foreign exchange sources ${ }^{1}$ (Rahmawati et al., 2020, 2), including Indonesia, which is one of the countries that have various types of tourism, namely natural tourism, social tourism, and cultural tourism spread from Sabang to Merauke (Devy and Soemanto, 2017: 34).

The Indonesian government has continued to strive in the development of tourism since 1978. This was stated in TAP MPR No. IV/MPR/1978, that tourism needs to be

\footnotetext{
${ }^{1}$ Tourism has provided substantial foreign exchange for various countries. Indonesia as the largest archipelagic country in the world consisting of 17,508 islands or also referred to as the archipelago or maritime country, realizes the importance of the tourism sector to the Indonesian economy because Indonesia's tourism growth is always at the top in Indonesia's economic growth (Soebagyo, 2012: 153). Yoeti (1996: 282), explained that based on World Tourism Organization statistics from 1.3 billion tourists in the world, only 4 million visited Indonesia while the rest visited Malaysia, Thailand, and European countries. Seeing the problem above means that the interest of tourists visiting Indonesian tourist objects is still low because so far, Indonesian tourism is still not optimal in its development. Apart from that, in Indonesia, tourism is the number three foreign exchange earner after oil and textiles before the Legian, Kuta, and Bali bombings. This proves that the tourism service industry has considerable potential to become the backbone of the economy in the future. Although the development is still not optimal. Government efforts to attract both foreign and domestic tourists are carried out with various concepts called a trilogy, namely creating tourism that includes products, marketing, and institutional (Peringatan, Windiani, and Sulistyowati, 2013Iyangjaya, t.t.: 3).
}

increased and expanded to increase foreign exchange income, increase employment, and introduce culture.

Guidance and development carried out for tourism must be carried out with due regard to the preservation of the culture and personality of the country. Therefore, it is necessary to apply measures and arrangements that are more directed based on integrated policies, including the promotion of division, provision of facilities, and quality and smooth service (Devy and Soemanto, 2017: 34).

There is a lot of potentials that make Indonesia as one of the tourist destination areas, namely Indonesia has millions of natural tourism charms that are so beautiful, rich in cultural tourism as evidenced by the many historical relics and the diversity of arts and cultural traditions of the local people which are the main attraction of domestic tourists and foreign tourists (Soebagyo, 2012: 153).

One of the regions in Indonesia where various types of natural wealth have the potential to be developed is Sungai Penuh City, located in the western area in the form of a plateau. The most popular highland tourist destination in Sungai Penuh City is Bukit Khayangan. Moreover, this destination is designated as the tourism icon of Sungai Penuh City because it was once named the Champion of the Most Popular Plateau at the event Anugerah Pesona Indonesia (API) and appreciation of Indonesia's Most Popular Tourism by the Indonesian Ministry of Tourism in 2017 (Dede, 2017).

Bukit Khayangan has a height of $\pm 1,500$ meters above sea level so that this tourist destination becomes a suitable venue for relaxing with family, friends by being presented with a beautiful view of the City of Sungai Penuh and its surroundings (Dede, 2017). The development of tourism in an area certainly has positive and negative impacts. The impact will affect the physical condition and socioeconomic order of the population around the tourist attraction (Purnamasari, 2011, 49-50). 
The development of tourism can increase the economic growth of the tourism sector, which comes from a large number of visitors or tourists visiting and staying at tourist sites. But the most crucial element in the development of an object and tourism attraction is tourists or visitors (Siam, 2015: 211).

The development of the Sungai Penuh City tourist destination, it can indirectly increase the income of local people and tourism businesses. The increasing number of foreign visitors can prove that Sungai Penuh City is a tourist area that is quite ogled by tourists or visitors who travel.

Departing from the above, the author intends to develop these problems and raise them into an article that illustrates and discusses supporting factors and inhibiting factors in the development of the Bukit Khayangan attraction, Sungai Penuh City. Then the development of attractions in Bukit Khayangan, Sungai Penuh City city, as well as the contribution of Bukit Kayangan Kota Sungai Penuh attraction.

\section{LITERATURE REVIEW \\ 1. Definition of Tourism}

Etymologically tourism (in Indonesian pariwisata) comes from two words, namely "pari" and "wisata" which are absorbed from the Sangsakerta language. The term "pari" means many, many times, complete and circling, while the word "wisata" means to travel or traveling (Yoeti, 2005: 103). There are several assumptions about the definition of tourism, from Spillane explaining tourism is a form of travel activities carried out individually or in groups from one place to another which is only temporary, as a form of an effort to get a match or balance and happiness with the environment in the social, cultural, nature, and science (Lutfi, 2013: 2; Sinurat and Fitrianti, 2016: 5).

Furthermore, according to Yoeti (Priyanto and Safitri, 2016: 77; Hamsani and Valeriani, t.t, 2014 : 43), tourism is a recreational activity that starts from one place to another to enjoy travel, sightseeing, and recreation and is not the intention to make a living. Tourism is an activity that has existed since time immemorial. Tourism in ancient times simple the shape known as the "excursion," but with the development of science and technology, the activity of the excursion developed into a broader movement.

In Undang-Undang Nomor 10 Tahun 2009 Regarding Tourism, Article 1 paragraph 3 explains tourism is a diverse form of tourism activities that are supported by facilities and infrastructure, supported by services that have been provided by the community, entrepreneurs, government and regional governments.

From some of the views on tourism above, it can be concluded that tourism is all forms of activities that occur in the community, relating to tourists, that is, people who travel as a form of exercise or actions of someone's temporary travel that is carried out consciously on their own will, which aims to enjoy the object of tourism (Lutfi, 2013: 2).

\section{Kinds of Tourism}

Travel tours have various types and specific destinations, differences in the types of models that cause the presence of multiple types of tourist destinations. So in an area, many kinds of tourism must be developed. Development based on tourism potential contained in the area.
According to Pendit (1990: 38), at this time there are many types of tourism, among others; tourism, religion, cultural tourism, nature reserve tourism, social tourism, sports tourism, industrial tourism, maritime tourism, agricultural tourism, commercial tourism, pilgrim tourism, honeymoon tourism, adventure tourism, convention tourism, and other types of tourism. Based on the situation and conditions in the development of the world of tourism contained in an area or country that wants its tourism industry to be developed and developing

\section{Tourism Development Strategy}

According to Rangkuti (2002) (in Hamsani and Valeriani, t.t: 43-44, 2014), quoted from Chandler's opinion, a strategy is a tool used to achieve specific goals related to long-term goals, follow-up programs, and also priority allocation of resources. Based on Gamal Suwantiro's opinion, in implementing a tourism development strategy, there are several key steps that must be considered, namely: first in the short term focused on optimization, second in the medium-term focused on consolidation, and third, in a long time focused on development and dissemination.

According to Murphy (1998, year ???(in Purnamasari, 2011: 51), in the development of tourism, aspects of the local community have become a commitment and agreement that must be realized to create growth in sustainable tourism, which emphasizes the creation of quality of resources, quality of visitor satisfaction, and the quality of life of local people.

Based on the capabilities and opportunities that are capable of tourism development needs to be realized to increase the economic growth of the community through the empowerment of the people's economy, and tourism also needs to create new tourism packages such as ecotourism or agrotourism. This type of tourism can have an impact on the local community, in addition to not requiring significant expenditure (capital), the local community can be involved in the development of tourism and the benefits that can be felt by the people in the region. In developing tourism to support the economy, several things need to be considered, as follows:

a. To improve the quality of tourism services and environmental sustainability, regulations need to be established to create quality tourism and take firm action in the event of a violation of established rules that do not favor the interests of certain parties.

b. In managing tourism, it is necessary to involve the local community. This is important because there is some experience in the Tourism Destination Region ${ }^{2}$ (DTW), which in no way means the local community where there is no economic contribution felt by the surrounding community. Case example in the management of DTW in Wanukaka Beach, West Sumba Regency, East Nusa Tenggara. The DTW community is not allowed to be involved in managing DTW either to sell agricultural products, handicrafts or become employees or workers in that place.

c. Promotional activities carried out must vary, in addition to the Visit Indonesia Year campaign and program as previously done, these promotional activities also need to be done by establishing a reliable information system network and building good relationships with tourism

\footnotetext{
${ }^{2}$ Later in this article, the sentence Tourism Destination Region (in Indonesian Daerah Tujuan Wisata) is abbreviated as DTW only.
} 
information centers. With other countries, especially countries that have potential.

d. Inviting and appealing to the DTW community to be aware of the responsibilities, roles, functions, and benefits of tourism and to encourage the community to take advantage of the opportunities available to benefit them from the economic aspect. Here they are allowed to sell local products, helping them to hone skills and procure capital for businesses that generate profits.

e. Need to prepare the necessary facilities to support the smooth operation of the DTW, such as procurement and repair of roads, telephones, shopping centers, transportation, and other facilities around the DTW location that are needed by tourist visitors (Soebagyo, 2012).

\section{METHODS}

In this study, the authors used qualitative research methods (Sugiono, 2009), because the authors wanted to get in-depth data from various sources and data collection based on the facts found in conducting research, so in qualitative research data analysis was done to build hypotheses (Susanto and Kiswantoro, 2019).

The writing of this study was carried out in Sungai Penuh City and focused more on the case of developing the attraction of the Bukit Khayangan attraction in Sungai Penuh City. The types of data in this study are divided into two, namely: 1) Primary data, namely the opinions or arguments of the Tourism and Culture Service officials of Sungai Penuh City and Sungai Penuh community on the central issues being discussed; 2) Secondary data is a source that supports primary data that are considered relevant to the main problem. Secondary data is intended as a refinement of writing material on the understanding and discussion of authors sourced from books, journals, magazines, articles, newspapers, scientific papers, and so on.

In collecting data in this study the authors used several data collection methods, namely (Arikunto, 2014): 1) Observation method, in this study the authors used a type of participant observation, i.e., the author involved himself directly in making observations by coming directly to tourist sites; 2) Interview Method, this method is done by way of face to face with the resource person (informant). The interview method aims to retrieve data about the viewpoint of Sungai Penuh City's community towards the problem of developing a tourist attraction and data to support observation data; 3) Documentation method, this method is used to get data in the form of newspapers, book notes, minutes of meetings, magazines, agendas and so on.

The technique that used in this research is to use qualitative analysis which is divided into three types of data analysis, namely (Margono, 2009) Domain analysis, this analysis is aimed at obtaining a general description of Bukit Khayangan, Sungai Penuh City tourism, to analyze tourism understanding, and various kinds of tourism; 2) Taxonomic analysis, the authors use this analysis to examine the research material in more detail and in-depth about the causes of obstruction and support for the development of tourist attraction in Sungai Penuh City; 3) Componesial Analysis, the authors use Componential Analysis to analyze data related to tourism development (Sujarweni, 2014).

\section{RESULTS/ DISCUSSION}

1. Inhibiting and Supporting Factors for the Development of Attraction in Bukit Khayangan, Sungai Penuh City

In a tourist attraction development activity, there are inhibiting and supporting factors. Of course, with the existence of these two factors, there must be a solution to overcome the inhibiting factors and utilize supporting elements. Inhibiting factors become things that can hinder and complicate the development of tourist attraction Bukit Khayangan tourist attraction. However, the presence of supporting factors can facilitate and help the development of the attraction of the Bukit Khayangan attractions. Knowing these two factors can make it easier to develop attractions in Bukit Khayangan, Sungai Penuh City. Based on observations (2019) shows the following conditions:

\section{a. Supporting factors}

1) Geographical Conditions and Cultural Diversity

The attraction of Bukit Khayangan is $8 \mathrm{Km}$ from the center of Sungai Penuh City and can be reached by using a motorcycle taxi with a travel time of \pm 25 minutes and costs Rp. 15,000. According to Natardi (interview, 2019) states that tourists visiting Bukit Khayangan use more private vehicles to get to the location of attractions and not much use public transportation. But only a few who use motorcycle taxis, namely tourists from outside the area.

The diversity of natural scenery is a significant advantage of the Bukit Khayangan tourism sector compared to other Sungai Penuh City tours. In the development of the tourism sector, the strategic position and condition of the region are supported by adequate transportation access, which can also be an added value for tourism.

2) Managed by the Regional Government

The City of Sungai Penuh Government, through the Culture and Tourism Office, has carried out activities in support of the development of Sungai Penuh City tourism objects. The support provided by the government is not only material but also moral support. This has been done by the government both and cooperating with the community. According to Rudi Wijaya (Interview, 2019) stated the Bukit Khayangan tour is one of the existing tours of Sungai Penuh City, which is managed directly by the Culture and Tourism Office. Unlike the Bukit Impian tour, although it is located in Sungai Penuh City, it is governed by the private sector. The author sees that the contribution by the Tourism Office will be a strong impetus for the development of the attraction of the Bukit Khayangan attraction for the future.

3) Technology Optimization

It is undeniable that human life at this time can not be separated from the name of technology, especially information and education. Advances in information technology are considered sufficient regarding the targets in terms of promotion, including tourism promotion. This is because information technology reaches almost all levels of society. Jaka Putra Putra stated (Interview, 2019) that social media is currently beneficial in the promotion of Bukit Khayangan attractions, such as Facebook, WhatsApp, and Instagram. I very often send some photos and videos to social media, especially Facebook. I think one valid promotion is through social media. Also, the cellphone (cellphone) signal at the Bukit Khayangan location is excellent and supportive so that tourists do not find it difficult to communicate using social media. 


\section{b. Obstacle factor}

1) Facilities and infrastructure are still lacking

Tourism facilities and support in the City of Sungai Penuh attractions can be said to be less than optimal. For example, the access road to the location of a tourist attraction, even though it can be taken well, but the security between the road and the ravine is not fulfilled. As is known that the road to the Bukit Khayangan attraction on the hillside, the risk of accidents is quite high. There are two access roads to Bukit Khayangan, namely from Sungai Jernih Village and Ulu Air Village. The road from Sungai Jernih Village is safe enough to be accessed. But for the road from Ulu Air Village is very rarely accessed, not because it is inadequate but very sharp road bends accompanied by climbing make tourists afraid to access the road. Rudi Hartono (Interview, 2019) stated that the access road to Bukit Khayangan from Ulu Air Village is quite dangerous to access because the bends are very sharp. Although I am not a native of Ulu Air Village when I want to go to the field, I prefer to access the road in Sungai Jernih Village because it is safer for safety. Not only me, but most of the other farmers also access the road from Sungai Jernih Village.

In addition to roads, electricity has not yet entered the Bukit Khayangan tourist attraction. The electricity supply there uses generators and solar power which electricity is still limited, so at night making the Bukit Khayangan attractions can not be visited at all. Rudi Wijaya stated that even though the Bukit Khayangan tourist attraction has not yet entered electricity, in the future, the government will provide electricity supply at the location of the tourist attraction so that at night the tourist attraction can be visited and no longer use lighting equipment.

There is also no adequate lodging in the tourist destination area of Bukit Khayangan, only the Local Government Mess (Mess Pemda) that does not deserve to be used as an accommodation. As is known, lodging is one part that can not be separated from attractions. If shelter is not immediately developed, it will be able to reduce the attraction of existing attractions. Similarly, lodging, as well as restaurants in the Bukit Khayangan tourist attraction, are not yet available, only small stalls are available that sell snacks and drinks. Natardi (Interview, 2019) stated that a restaurant is very much needed during a tour, in which a restaurant serves an authentic culinary area of the tourist attraction. But when traveling to Bukit Khayangan, most visitors bring food from the Sungai Penuh market.

\section{Development of Attractiveness in Bukit Khayangan Tourism Object Sungai Penuh City}

The location of the Bukit Khayangan attraction located 8 $\mathrm{Km}$ from the center of Sungai Penuh City is fitting to make the area a natural tourist attraction. Although the distance is quite far from the center of Sungai Penuh City, this does not make this tourist attraction quiet to be visited by tourists. Also, the location of the Bukit Khayangan attraction is close to the Puti Senang Flower Park attraction and the Tapan Hill attraction.

In increasing the number of tourists visiting the Bukit Khayangan attraction, it has to increase its attractiveness. Talking about increasing the attractiveness of a tourist attraction requires the development of these attractions. Based on the results of observations (2019), the authors see several things must be built and improved in the development of the attraction of Bukit Khayangan attractions:

a. Improve Road Access

Safe road access is essential for the safety of tourists. With the iron safety along the road to the location of the Bukit
Khayangan attraction will make visitors not feel hesitant when passing through the road. Natardi (Wawacara, 2019), roads are one of the infrastructures that require high costs. In this case, the author sees the road to the location of Bukit Khayangan attractions in Ulu Air Village should not need to be built because the risk of accident rates is high. But because it has already happened, the right solution is to improve the bend and climb so that it does not become too steep, so that the community can pass it.

b. Increase in Electricity Supply

Electricity is also essential to add to the attraction of the Bukit Khayangan attraction. As is known that humans today can not be separated from electricity. Although currently available generators and solar power plants, all of them can not produce great power as electricity supply in the Bukit Khayangan tourist attraction. Therefore, it is essential to think about building and adding enough electrical power to supply the electricity in the Bukit Khanyangan tourist attraction.

c. Building Lodging

Lodging can also add to the attraction of the Bukit Khayangan attraction. Tourists who come from outside the area need adequate lodging for a place to rest. Because lodging is far from the location of attractions, this can make tourists do not want to linger on a tourist attraction. Therefore, with the inn, tourists have the opportunity to stay with a long time at a tourist attraction. Not apart from that, in terms of lodging is needed a high level of security. As it is known that the tourist attraction of Bukit Khayangan is isolated from the center of Sungai Penuh City. Remote locations are often used by teenagers to date and do things that are not good. So in this case must be monitored by the government.

d. Building a Restaurant

If there is an authentic culinary area of Sungai Penuh City in the Bukit Khayangan tourist area, it will be a unique attraction in supporting the development of these tourism objects. As is known in the Bukit Khayangan tourist attraction, there are no restaurants. Therefore restaurants are essential to be built.

e. Establish Cooperation with Surrounding Communities

Collaboration with the community around a tourist attraction is useful for the security of a tourist attraction. Although this tourist attraction is managed directly by the government, the government cannot cover all parts of the location of the tourist attraction. In this case, it is essential to establish cooperation with the local community. The community can contribute and have a role in planning. First, giving donations in the form of support for the planner and the activities he undertakes. Second is the contribution in terms of wisdom and knowledge in the development plan, as well as in identifying from the planning actors. The third is a vital function, namely as a supervisor in their rights and the rights of others in designing and submitting policies (Purnamasari, 2011).

\section{f. Promotion through Electronic Media}

One of the most effective ways of development today is through electronic media. Promotion through advertising on National Television is one example. With these advertisements, all of Indonesia can know about the attractions of the Bukit Khayangan River City. But for this type of promotion can be costly because the ads can reach large areas. In addition to advertising on television, development on the internet is no less enjoyable. Internet media is one of the promotions through electronic media; the internet media does not cost a large enough. The Culture and Tourism Office 
of Sungai Penuh City does not have an Official Website that can be accessed in finding information about tourism in Sungai Penuh City. Likewise, with social media such as official Facebook or Instagram pages that display this information (Jaka Putra, Interview, 2019).

The author sees that promotions carried out on the internet or social media already exist, but that is through an account belonging to an employee or employee of the Culture and Tourism Office of Sungai Penuh City. Also, information about the object displayed is incomplete. Therefore, promotion needs to be done by creating a unique website about tourism in Sungai Penuh City.

g. Reforestation

Reforestation is the replanting of deforested debt. Looking at the conditions around the Bukit Khayangan attraction can be said that not many trees can prevent landslides. Although this has never happened landslides. So it is better to realize reforestation because it is useful to avoid avalanches. In addition to avoiding landslides, the growing trees can also provide coolness to visitors of the Bukit Khayangan attraction.

\section{CONCLUSION}

Based on the description above, the authors conclude as follows: Supporting factors for the development of Bukit Khayangan attractions include; geographical conditions and cultural diversity, managed by local government, and technology optimization. While the inhibiting factors in the event of Bukit Khayangan attractions are inadequate infrastructure found on roads, electricity, restaurants, and also lodging that does not yet exist around the Bukit Khayangan area.

In developing the Bukit Khayangan tourism object, eight things should be built and improved by the Sungai Penuh City Regional Government, among others; improve road access, increase electricity supply, build lodging, build restaurants, collaborate with surrounding communities, promote through electronic media, and reforestation.

\section{REFERENCES}

Arikunto, Suharsimi. (2014). Prosedur Penelitian, Suatu Pendekatan Praktik. Jakarta: PT Rineka Cipta.

Dede, Hendri. Negeri di Atas Awan di Sungai Penuh Ini Sabet Juara I Dataran Tinggi Terpopuler di Indonesia. (online). (http://jambi.tribunnews.com/, accessed 18 December 2019.

Devy, Helln Angga and Soemanto, R. B. (2017). "Pengembangan Obyek dan Daya Tarik Wisata Alam sebagai Daerah Tujuan Wisata di Kabupaten Karanganyar". Jurnal Sosiologi Dilema, Vol. 32, No. 1.

Hamsani and Valeriani, Devi. (2014). "Blue Ocean Strategy Pengembangan Pariwisata di Propinsi Kepulauan Bangka Belitung". Jurnal Ekonomi Akuntansi dan Manajemen, Vol. 13, No. 2.

Peringatan, Admesia Iyangjaya, Windiani, Reni, and Sulistyowati. (2013). "Strategi Pemasaran Pariwisata Kabupaten Jepara”. Jurnal Penelitian Ilmu Pemerintahan FISIP Undip, Vol. 2, No. 4.

Luthfi, Renaldy Rakhman. (2013). Peran Pariwisata Terhadap Kesejahteraan Masyarakat di Sektor
Lapangan Pekerjaan dan Perekonomian. Universitas Brawijaya: Fakultas Ekonomi dan Bisnis.

Margono. (2009). Metodologi Penelitian Pendidikan. Jakarta: PT Rineka Cipta.

Pendit, Ny. S. (1990). Ilmu Pariwisata, Sebuah Pengatar Perdana. Jakarta: PT. Pandnya Paramita.

Priyanto and Safitri, Dyah. (2016) "Pengembangan Potensi Desa Wisata Berbasis Budaya Tinjauan Terhadap Desa Wisata Di Jawa Tengah". Jurnal Vokasi Indonesia, Vol. 4, No. 1.

Purnamasari, Andi Maya. (2011). "Pengembangan Masyarakat untuk Pariwisata di Kampung Wisata Toddabojo Provinsi Sulawesi Selatan". Jurnal Perencanaan Wilayah dan Kota, Vol. 22, No. 1.

Rahmawati, Nurul dkk. (2020). "Peran Dinas Pariwisata dalam Pengelolaan Wisata Minat Khusus di Kabupaten Ponorogo", Jurnal Ilmiah Pariwisata, Vol. 25, No. 1 .

Siam, Nurbaiti Usman. (2015). "Peranan Dinas Kebudayaan dan Pariwisata Kabupaten Lingga dalam Pengembangan Objek Wisata". Jurnal Ipteks Terapan, Vol. 8, t.n.

Sinurat James and Fitrianti, Dewi. (2016). "Analisis Ekonomi Kawasan Wisata Taman Nasional Gunung Gede Pangrango Kecamatan Cipanas Kabupaten Cianjur". JIMFE (Jurnal Ilmiah Manajemen Fakultas Ekonomi), Vol. 2, No. 2.

Soebagyo. (2012). "Strategi Pengembangan Pariwisata di Indonesia". Jurnal Liquidity, Vol. 1, No. 2.

Sugiono. (2009). Metode Penelitian Kuantitatif dan Kualitatif. Bandung: Alfabeta.

Sujarweni, V. Wiratna. (2014). Metodologi Penelitian. Yogyakarta: PT Pustaka Baru.

Susanto, Dwiyono Rudi, and Kiswantoro, Amin. (2019). "Strategi Pengembangan Hutan Pinus Grenden Berbasis Ekowisata Di Magelang". Jurnal Ilmiah Pariwisata, Vol. 24, No. 3.

Yoeti, Oka A. (1996). Pengantar Ilmu Pariwisata. Bandung: PT. Angkasa.

Yoeti, Oka A. (2005). Perencanaan Strategis Pemasaran Daerah Tujuan Wisata. Jakarta: Pradnya Paramita. 